\title{
Problems in HOTS Application: A Study of Teacher's Reflection and Decision Making
}

\author{
${ }^{1}$ Intan Riza Aprilya, ${ }^{2}$ Muhammad Saifuddin \\ Universitas Pesantren Tinggi Darul Ulum Jombang \\ *Corresponding Author \\ Email: saifuddin.unipdu@gmail.com
}

\begin{abstract}
Higher Order Thinking Skill (HOTS) is a demanded strategy to be applied in any teaching activities, including English teaching and learning process. This HOTS application offers attainable learning outcomes to the teachers when conducting teaching activities. Teachers are able to see how far students can learn based on cognitive, affective, and psychomotor aspect. However, there were problems which teachers found. It triggered the teachers to have a reflection on what problems they had. It also challenged them to encounter the problems to keep the implementation of HOTS successful. By this identification of the research problem, this research was carried out to figure out teacher's self-reflection as well as the decisions how to encounter them. In line to the research purpose, a qualitative research design was applied. Interview was used to obtain the data. Furthermore, the results showed that the students acted unmotivated and lack of confidence during learning activities; they lacked English interest; and HOTS was not applied properly based on its stages. Then, decision making was established in terms of teaching strategies and lesson planning. In conclusion, despite the importance of creating HOTS to invite students to be creative and critical, problems still remained. It implied teachers' responsibility to decide the actions as solutions. In this case, teachers' self-reflection did assist to provide sustainable analysis and to ensure HOTS application to improve teaching and learning process.
\end{abstract}

Keywords: Self-Reflection, Higher Order Thinking Skill (HOTS), Learning Taxonomy

\section{INTRODUCTION}

Learning goal describes students to the expected ability which presents certain ability and also how they learn. A successful learner will establish meaningful learning, coherent and relevant knowledge by the support of instructional guidance (Webster \& Andre, 2018). In a way of succeeding their learning, there must be an insight decision making taken by students. This ability of problem solving tends to help students achieve learning goal and their expectation for a good learning. In case of establishing good decision making, activating students' cognitive ability seems to be important part. Furthermore, in a learning process, students' understanding of the lesson can also be measured from students' cognitive level based on the learning taxonomy. Schunk (2012) states that learning is a matter of gaining knowledge, discover students' own learning, gaining sets of questions, and maintain cognitive process.

Higher Order Thinking Skill (HOTS) proposes learning path that students need to steps the learning activities sequentially. This HOTS also describes abilities which students will possess when they learn through typical activities. It is a level of knowledge aspect bringing students to level of critical thinking and creativity. Students are always suggested to achieve this higher level of cognitive skill 
(Anderson \& Krathwohl, 2001). It implies that learning activities should enable students to gain skill from simple to complex one. This cognitive aspect involves remembering, understanding, applying, analyzing, evaluating and creating level.

Though HOTS offers more benefits to improve the learning outcomes, teachers may mislead their teaching activities. A study conducted by Ahmad (2018), he found teacher's weakness in implementing LOTS and HOTS. In the learning process the teacher did the activities representing low and high level thinking skills. However, the teacher missed the evaluation stage while applying HOTS. Such conditions make the learners passive to receive the materials delivered by the teacher. By knowing the weakness of teachers in teaching HOTS, then, reflection is required to support the teacher's ability to improve the knowledge and development of their professionals.

The common problem occurred is that the learning process does not represent HOTS; in fact, the learning process is still at LOTS (Lower Order Thinking Skill) level. There is a close relationship between LOTS and HOTS in which they present the order of learning level. It means that LOTS should be well achieved before going to HOTS. This case shows that not all teachers understand HOTS well. They have different perceptions and pedagogical knowledge about it. The possibility of the teacher to understand the concept of HOTS is still lacking. In addition, teachers may experience difficulties when implementing HOTS in the learning process. It was seen from preliminary study which was done as a part of this research. It was found that the teacher implemented HOTS in the learning process. However, he tended not to apply the stages of HOTS depending on the situation and condition of the students.

Reflective teaching provides rigorous analysis as it is defined as a selfassessment of teaching, reveal, or identify deficiencies in the teaching by knowing what difficulties the teachers face in order to determine strategy or next step requiring revision or improvement (Kember, et.al., 2008). It is obvious that teachers are given the opportunity to trace how to build their teaching knowledge. Through its development and the ability to recognize the knowledge, teachers are more responsible to the problems. Problems during teaching may occur depending on either teacher or students' learning difficulties. A need of revealing the problem leads to the decision making.

Looking at this point, it was necessary to investigate teacher's problems when implementing HOTS and to reveal what decisions as solutions he proposed. Furthermore, this research also aimed at describing teacher's self-reflection on problems appeared during the implementation of HOTS in the learning process.

\section{Cognitive Domain}

Cognitive domain is represented in Bloom taxonomy which shows stages form lower level to higher level. There are 6 stages of cognitive domain. They are remembering, understanding, applying, analyzing, evaluating, and creating (Anderson \& Krathwohl, 2001). 


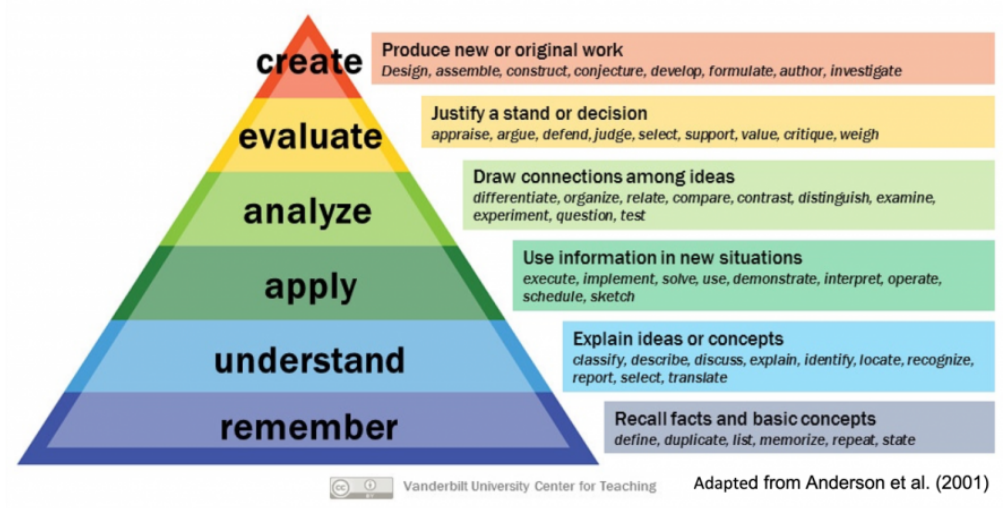

Figure 1. Bloom Taxonomy - Cognitive Domain

Looking at the figure 1, it describes that this taxonomy includes different components in which they are connected from one to another. In the learning process, this cognitive taxonomy provides sequent and ordered learning. Students need to learn from remembering stage as the lowest level of cognitive domain then they learn one step higher, and so forth. Obviously, each has a different implication and description in what way students will learn based upon this taxonomy. The cognitive domain will be seen in learning taxonomies by using bloom taxonomy tables. This figure is used as a reference when writing learning objectives to find an appropriate action verb. As a result, the teacher's job is to create a learning environment that students engaged in learning activities and supports appropriate learning activities to achieve desired learning outcomes (Bigg, 2003).

\section{HOTS (Higher Order Thinking Skill)}

Higher-order thinking, known as higher order thinking skills (HOTS) is a concept of education reform based on learning taxonomies (Bloom's taxonomy). HOTS is the last three higher levels they are; analyzing, evaluating and creating (Brookhart, 2010). The importance of applying HOTS in the learning process is to enhance the strength of student character education with HOTS learning and assessment to have skills such as critical thinking, problem solving, creative, and communication skills.

By the last three stages of HOTS, it is expected that students can develop the ability to analyzing, evaluating, and creating. Limbach \& Waugh (2010) propose five steps to develop the ability to think critically, namely questioning, practicing, improving understanding, practicing feedback and assessing learning. So the students have critical thinking that can be used to problem solving by involved students in problem solving, that's can develop the ability to analyze and evaluate that the students are more creative and motivated to build their ability to have a good communication skill. So HOTS learning becomes meaningful for students.

Through the learning activities, it is easy to see how someone learns during learning process. Hamalik (2010) describes that learning activities is the process of interaction (teachers and students) in order to achieve learning objectives. Learning activities of HOTS are three stages in teaching-learning process namely analyzing, evaluating, and creating. 
Table 1. Cognitive Taxonomy - HOTS stage

\begin{tabular}{|c|c|c|}
\hline Stages & Function & Action verb \\
\hline $\begin{array}{l}\text { Analyzing } \\
\text { Evaluating } \\
\text { Creating }\end{array}$ & $\begin{array}{c}\text { Examine and break information } \\
\text { Present and defend opinions } \\
\text { Compile information in } \\
\text { different way }\end{array}$ & $\begin{array}{l}\text { Analyze, classify, assume, etc. } \\
\text { Agree, appraise, assess, etc. } \\
\text { Adapt, build, change, etc. }\end{array}$ \\
\hline
\end{tabular}

Based on Anderson and Krathwohl (2001), the last three higher levels are analyzing, evaluating and creating. The first stage is analyzing in this step teachers must examine and break information into parts by identifying motives or causes and the students must be distinguished, classified and related the statement or questions. The actions included in this function are analyze, classify, and being able to distinguish between the components or parts. When one is analyzing, he/she can illustrate this action function by creating charts, surveys, diagrams, or graphic representations.

The second stage is evaluating. In this step, the teacher present and defend opinions by making judgments about information or quality of work. The students must be appraised, assesses on a basic of specific standards and criteria based on the action verbs. Making judgments based on criteria and standards through checking and critiquing. Critiques, recommendations, and reports are some of the products that can be created to demonstrate the processes of evaluation.

The last stage is creating. Teachers compile information together in a different way by combining elements in a new pattern or proposing alternative solution. In this step, students must produce new ideas or ways of viewing thing, recognize elements into new pattern or solution through adaptation, building, or changing. Creating stage requires students to put parts together in a new way into something new and produce solution.

\section{Reflective Teaching}

Reflective teaching is a self-assessment of teaching, reveal, and identify deficiencies in the teaching by known the difficulties of the teachers in order to determine which strategy or next step requires revision or improvement (Kember et al. 2008). Such revision or improvement by the teacher which required changes that often unconscious brought new beliefs and leads to new perspectives for the next step. The aims of reflective teaching are to know the extent to which students' interests follow for learning and to know the success rate of the learning strategies and techniques applied by teachers. When teachers are involved in the process of teaching some events occur that they use to have a better understanding of their teaching, gained new experience in teaching, because every students responds with learning different ways. The teacher knows whether the learning with strategies and techniques that are applied are able to attract students' interest in following the learning.

\section{METHOD}

This research intended to identify what problems or difficulties were found by the teachers and also how the teacher reflected them to determine the sustainable solution. To be able to collect data and meet the research aims, a qualitative research design was proposed since it gave clear descriptions of phenomenon (Creswell, 2009). It was undertaken to teachers teaching experiences while teaching English 
to the students of Islamic Senior High School. The participant of this research was the English teacher of tenth and eleventh year students of science program. The teacher was invited to interview sessions. It took three times of interview. The data of this research were in the form of the teachers' problems in while implementing HOTS and decisions made by the teacher on the phase of reflection.

\section{Instruments}

To obtain the data, interview was carried out. As it aimed to figure out problems faced by the teacher in implementing HOTS, interview gave spaces to obtain these kinds of data. This also described how the teacher reflected the problems to determine further action needed. The questions covered whether students acted positively toward the implementation of HOTS, what kind of obstacles teacher found, how to maintain HOTS in learning process, what problems were often faced by the teacher when applying HOTS level to his teaching.

\section{Procedures}

This research collected the data in relation to problems or difficulties faced by the teacher in implementing HOTS. To collect the data from the interview, transcribing the interview was needed to be done firstly. It enabled this research to code and decode the teacher's statements. Tabulating the data identified was also administered to figure out the implication of problems appeared.

\section{RESULTS AND DISCUSSION}

The findings of the research showed that the teacher faced some problems in learning activities during the use of HOTS. The teacher's difficulties are presented in this section. They are: (1) The teacher found the students unmotivated, tired, bored, lazy, and lack of confidence (2) The teacher found the students uninterested to English learning (3) The teacher did not apply HOTS according to the stages.

\section{Students' lack of learning motivation}

The situations and conditions did not support the teaching learning process because the students felt unmotivated, tired, bored, lazy and lack of confidence. The teacher had his lesson plan before teaching. However, the class atmosphere was different and insisted the teacher to teach them accordingly. These types of students' attitude had been uncovered by the teacher since the students were mostly from boarding house. In line, the teachers often planned different teaching strategies. However, it remained the problems to the effectiveness of teaching and learning process. Some learning activities might be omitted as the teacher decided not to focus on how to succeed the lesson plan.

\section{Difficulties on Students' Lack of English Learning Interest}

Learning interest could be the source of students' motivation to do learning activities. It could not be neglected that once the students felt that they were not interested in the English subject, it was hard for them to get involved in learning activities. Of course, it triggered considerable problem when the students were not involved in learning process then more serious problem would follow as its consequences. 
Looking at this type of problem, it seemed that the students did not always gain their courage to learn English because they did not really like English. Further, some of them had a limited vocabulary, some of them could speak English and understood the material but they were embarrassed to express the ideas. The difficult thing in teaching English based on HOTS was when asking all students to answer the questions using English. If the teacher asked questions and conveyed the materials based on HOTS learning in Indonesian, the lesson and discussion were more interesting for students. The main problem was in communication between the teacher and students regarding the use of English.

\section{The teacher did not apply HOTS according to the stages}

The HOTS stages included analyzing, evaluating, and creating. Every stage of HOTS had a sequence and a correlation. The goal of HOTS was to ensure students to think critically. The relationship between HOTS stage and critical thinking was that the teacher was able to carry out HOTS to lead the students think creatively and innovatively to solve the problems using their knowledge and to make the right decisions.

Sometimes, the teacher could not differentiate what kind of skill represented in the stages. The teacher did not always put the analyzing stage at the beginning. Occasionally, before evaluating stage the teacher applied the creating stages at the beginning. It can be said that the route of learning activities did not have the order as it implied in learning taxonomy.

On the other hand, self-reflections helped the teacher to conduct selfevaluation to the learning of teaching, focused on identifying the difficulties in implementing HOTS during the learning process and how are reflections in the difficulties. Its purpose was to improve the quality of teaching and students' learning. There are reflections based on the difficulties that were found in implementing HOTS learning process.

\section{(1) Reflecting to students' lack of learning motivation}

When this kind of problems appeared, the teacher found himself difficult to keep HOTS working. These conditions or situations of students affected the teaching-learning process. Students were not interested enough in the way of the teacher taught. Therefore, the teacher could be more aware of these conditions. Looking at this point, the teacher used games to make students focus on learning. The games with sound and images could build students 'imagination and confidence, namely a video, by asking questions that could build students' imagination to think critically and creatively through video. These questions could generate students' curiosity about what should appear in the video. Students had different opinions or imaginations about the video. So that teachers and students could find valid answers to the teacher's questions. These things needed to try out by the teacher. The goal was to get their attention.

\section{(2) Reflecting to Students' lack of English learning interest}

The teacher found student lack of interest in English. They tended to do passively. This problem came from the lack of student motivation in learning. Seeing this thing, the teacher started the lesson with simple questions for students, 
such as what a movie did you watch on TV last night? The students' limited vocabulary became another reason to their involvement in English learning and it often appeared when students were asked to answer questions in English. Consequently, the teacher invited the students to translate or change the English statements or questions to Indonesian language together. The teacher did not blame students when they answered the questions wrongly because many students were afraid of answering. It was because when the teacher blamed them, they hardly got confident.

The teacher tended to use group discussion by using animation video. The activity of discussion offered a good effect on building students' motivations to engage them in English learning. From the animation video, it might be the teacher who needed to try both English and Indonesian questions interchangeably to make students' lessons enjoyable. The purpose of group discussions was to attract their attention and invited students to share their ideas. Another reflection was that the teacher created role-play in the form of drama, the students needed to the story based on their own understanding.

\section{(3) Reflecting to the teacher who did not apply HOTS according to its stages}

There were three stages of HOTS namely analyzing, evaluating, and creating. However, the teacher still could not differentiate each HOTS stages in the learning process and reluctant to apply HOTS in the sequence. This problem might be affected by teacher's experiences. Moreover, the teacher did not always put the stages of analyzing at the beginning. It seemed that the activities firstly done represented evaluating rather than analyzing.

The reflection assured the teacher to check and recheck the activities. Though the teacher applied different learning strategies, there must be focus of sequenced activities to lead the students to bring out HOTS and achieved the learning outcome.

\section{CONCLUSION}

Regarding the objectives of this research that it intended to figure out the problems faced by the English teacher when teaching students under HOTS learning model and to find out the implication of teacher's self-reflection to propose solutions, this research summarized that there were three categories of teacher's reflections were presented based on the problems found. The first was teacher's reflections on students' lack of learning motivation. In this case, the teacher proposed games and video. The second was that when the teacher found them lacked of English learning, he commenced activities by raising simple questions for students and used both English and Indonesian question interchangeably. Animation video, group discussions and role-play were as follow up. The third was teacher's reflection on the teacher who did not apply HOTS according to the stages.

The findings of this research imply immediate action that the teacher should consider factors which may trigger learning disruptions. Understanding the principles of HOTS in learning process will improve the smoothness and meaningful learning. In addition, self-reflection utilizes teacher means of measurement to find out causes and determine the decisions. It is thus always suggested for teachers that leading students to higher thinking skill level needs 
sustainable teaching mastery which may include mastering and developing learning materials, running well-planned teaching methods, and using of various teaching sources.

\section{REFERENCES}

Ahmad, Kurniawan. (2018). The implementation of teaching LOTS and HOTS in English teaching-learning process in senior high school. RETAIN, 6(1), 121128

Anderson, L. W. \& Krathwohl, D. R. (2001) A Taxonomy for Learning, Teaching, and Assessing: A Revision of Bloom's Taxonomy of Educational Objectives. Allyn \& Bacon

Biggs, J. (2003). Aligning teaching for constructing learning. Higher Education Academy, 1(4).

Brookhart, S. M. (2010) How to assess higher-order thinking skills in your classroom. ACSD Member Book. http://www.ascd.org

Creswell, J. W. (2009). Research design: qualitative, quantitative, and mixed methods approach (3 ${ }^{\text {rd }}$ ed.). Sage.

Hamalik, O. (2001). Learning strategies. Bumi Aksara

Kember, D., McKay, J., Sinclair, K., \& Wong., F. K. Y. (2008). A four category scheme for coding and assessing the level of reflection in written work. assessment \& evaluation in higher education, 33(4), 369-379.

Limbach, B., \& Waugh, W. (2010). Developing higher level thinking. Journal of Instructional Pedagogies, 3(6), 1-9, http://www.aabri.com

Schunk, D. H. (2012). Learning theories: An educational perspective (6 $6^{\text {th }}$ ed.). Pearson

Webster, R \& Andre, J. (2018). Flexible student alignment for self-directed learning and 21 century skills development. 